\title{
Reactivity of $\beta$-enamino ester of benzo[f]chromene: One pot synthesis of isolated and heterocycle-fused derivatives of benzo[f] chromene
}

\author{
Eman Abd El-Rady* and Islam Helmy El-Azab \\ South Valley University, Faculty of Science, Chemistry Department, Aswan 81528, Egypt \\ *Corresponding author at: South Valley University, Faculty of Science, Chemistry Department, Aswan 81528, Egypt. \\ Tel.: +2.097480446; fax: +2.097480450. E-mail address: emanelradi@hotmail.com (E.A. El-Rady).
}

\section{ARTICLE INFORMATION}

\section{Received: 22 August 2011}

Received in revised form: 27 September 2011

Accepted: 18 October 2011

Online: 31 March 2012

\section{KEYWORDS}

Spectral analysis

Elemental analysis

Vilsmeier reaction

Phosphorus oxychloride

Benzo[f]chromeno[2,3- $d]$ pyrimidine

Benzo[f]chromeno[2,3-d][1,3,4] thiadiazolo[3,2a]pyrimidine

\begin{abstract}
The formation of isolated and fused benzo[f]chromene derivatives was achieved via reacting ethyl 3-amino-1-phenyl-1H-benzo[f]chromene-2-carboxylate (1) with some selected reagents under basic conditions. The new compound, ethyl 3-(dimethylaminomethyleneamino)-1phenyl- $1 H$-benzo[f]chromene-2-carboxylate (2) was prepared from compound 1 and $N, N$ dimethyl formamide in presence of phosphorus oxychloride under mild conditions in excellent yield using Vilsmeier reaction. Also, 10-amino-12-phenyl-9-sulfanyl-12H-benzo[f] chromeno[2,3-d]pyrimidine-11(10H)-one (12), 10-aryl-14-phenyl-14H-benzo[f]chromeno $[2,3-d][1,3,4]$ thiadiazolo[3,2- $a]$ pyrimidine-13-one (15), ethyl 3-(4-oxo-2-thioxothiazolidin-3yl)-1-phenyl-1H-benzo[f]chromene-2-carboxylate (18), ethyl 3-(4-phenyl-2-thioxothiazol$3(2 H)$-yl)-1-phenyl-1H-benzo[f]chromene-2-carboxylate $(\mathbf{2 0})$, ethyl 3-acetamido-1-phenyl$1 H$-benzo[f]chromene-2-carboxylate (21), and 10-amino-9-methyl-12-phenyl-12 $H$-benzo[f] chromeno[2,3-d]pyrimidine-11(10H)-one (23) were prepared. The structures of these compounds were established by elemental analysis, IR, MS and NMR spectral analysis.
\end{abstract}

\section{Introduction}

Chromene and fused chromene derivatives are an important class of compounds; they are widely distributed in nature [1]. Among chromene derivatives are biologically interesting compounds showing antimicrobial activities [2-4], inhibitors of influenza virus silidoses [5,6], compounds with antihypertensive [7] and anti-allergic activity [8] and hair growth stimulant properties [9]. Also, chromene derivatives were found useful as antiviral [10], antiproliferation agents [11], as sex pheromone [12], with antitumor [13], central nervous system activity [14] and as anti-HIV agent [15]. Some of their derivatives were utilized in the synthesis of macrocyclic ligands [16]. Due to these interesting properties of chromene derivatives and in continuation of our efforts directed to the synthesis of heterocyclic compounds [17-20] we wish to report here the results of our investigation on the reactivity of ethyl 3-amino-1-phenyl-1H-benzo[f]chromene-2-carboxylate (1) in the synthesize of new fused and isolated chromene compounds.

\section{Experimental}

\subsection{Instrumentation}

Melting points were determined on a Gallenkamp electrothermal melting point apparatus and are uncorrected. IR spectra were recorded from potassium bromide discs using a Bruker Vector 22 FT-IR spectrophotometer. ${ }^{1} \mathrm{H}$ and ${ }^{13} \mathrm{C}$ NMR spectra were obtained in deuterated dimethyl sulfoxide as solvent at $300 \mathrm{MHz}$ and $75 \mathrm{MHz}$, respectively, on a Varian Gemini NMR spectrometer using TMS as internal standard. Chemical shifts are reported in $\delta$ units (ppm). Mass spectra were recorded on a Hewlett Packard MS-5988 spectrometer at
$70 \mathrm{eV}$. Elemental analysis was carried out at the Micro analytical Center of Cairo University, Egypt.

\subsection{Synthesis}

\subsubsection{Ethyl 3-(dimethylaminomethyleneamino)-1-phenyl- 1 H-benzo[f]chromene-2-carboxylate (2)}

A sample of compound 1 ( $3.44 \mathrm{~g}, 0.1 \mathrm{~mol}$ ) was dissolved in $10 \mathrm{~mL}$ of DMF, the reaction mixture was stirred and cooled to 0 ${ }^{\circ} \mathrm{C}$, and phosphorus oxychloride $(0.1 \mathrm{~mol}, 4 \mathrm{~mL})$ was added slowly. After the addition was complete, the mixture was stirred for one hour and then poured into stirred ice-water. A saturated solution of sodium hydroxide was added slowly. A solid product was precipitated, collected by filtration, washed with water and crystallized from ethanol (Scheme 1). Colorless crystals (DMF $\left./ \mathrm{H}_{2} \mathrm{O}\right)$. Yield: 73 \%. M.p.: $220-222^{\circ} \mathrm{C}$. IR $\left(\mathrm{KBr}, v_{\max }\right.$, $\mathrm{cm}^{-1}$ ): 1698 (CO). ${ }^{1} \mathrm{H}$ NMR $\left(300 \mathrm{MHz}, \mathrm{CDCl}_{3}, \delta, \mathrm{ppm}\right): 1.75(\mathrm{t}, 3 \mathrm{H}$, $\left.\mathrm{CH}_{3}\right), 2.47\left(\mathrm{~s}, 6 \mathrm{H}, 2 \mathrm{CH}_{3}\right), 4.52\left(\mathrm{q}, 2 \mathrm{H}, \mathrm{CH}_{2}\right), 7.54(\mathrm{~s}, 1 \mathrm{H}, \mathrm{N}=\mathrm{CH})$, 7.57-7.95 (m, 12H, Ar-H + CH-pyran). MS (m/z, (\%)): $400\left(\mathrm{M}^{+}\right.$, 25). Anal. calcd. for $\mathrm{C}_{25} \mathrm{H}_{24} \mathrm{~N}_{2} \mathrm{O}_{3}$ (400.47): C, 74.98; $\mathrm{H}, 6.04 ; \mathrm{N}$, 7.00. Found: C, 75.08; H, 6.33; N, 7.15\%.

\subsubsection{3-(Phenylaminomethyleneamino)-1-phenyl-1H-benzo [f]chromene-2-carboxylic acid (4)}

A mixture of 2 ( $1 \mathrm{mmol})$, and aniline (1 mmol) in $20 \mathrm{~mL}$ of ethanol containing $0.1 \mathrm{~mL}$ of piperidine as catalyst was refluxed for 2 hours. The compound formed during reflux was collected by filtration and re-crystallized from dioxane $/ \mathrm{H}_{2} \mathrm{O}$ to form compound 4 (Scheme 1). Colorless crystals (dioxane/ $\mathrm{H}_{2} \mathrm{O}$ ). Yield: 33 \%. M.p.: 210-212 ${ }^{\circ} \mathrm{C}$. IR ( $\left.\mathrm{KBr}, v_{\max }, \mathrm{cm}^{-1}\right): 1698$ (CO), $3119(\mathrm{NH})$. 


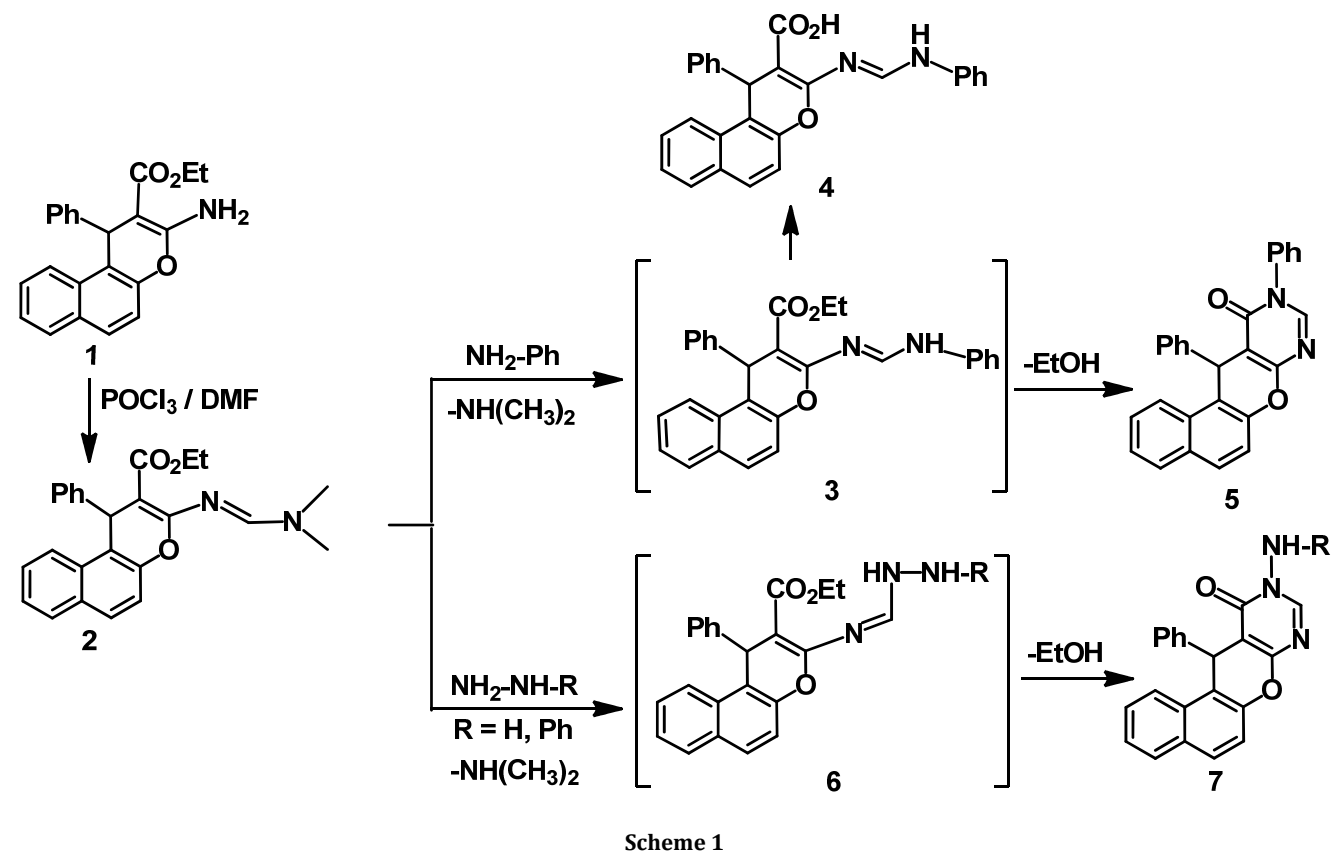

${ }^{1} \mathrm{H}$ NMR $\left(300 \mathrm{MHz}, \mathrm{CDCl}_{3}, \delta, \mathrm{ppm}\right): 7.72(\mathrm{~d}, 1 \mathrm{H}, \mathrm{N}=\mathrm{CH}), 7.75$ (d, H, NH), 7.76-7.99 (m, 17H, Ar-H + CH-pyran), 11.50 (s, 1H, $\mathrm{OH}) .{ }^{13} \mathrm{C}$ NMR (75 MHz, $\mathrm{CDCl}_{3}, \delta$, ppm): 38.12, 99.12, 116.23, $118.12,118.23,120.34,126.12,126.14,126.43,128.11,128.23$, $128.32,129.23,129.32,138.12,140.32,146.21,151.12,163.12$, 166.23, 170.65. MS $(\mathrm{m} / \mathrm{z},(\%)): 420\left(\mathrm{M}^{+}, 30\right)$. Anal. calcd. for $\mathrm{C}_{27} \mathrm{H}_{20} \mathrm{~N}_{2} \mathrm{O}_{3}$ (420.15): C, 77.13; $\mathrm{H}, 4.79 ; \mathrm{N}, 6.66$. Found: $\mathrm{C}, 77.43$; $\mathrm{H}, 4.95$; N, 6.75\%.

\subsubsection{0,12-Diphenyl-12H-benzo[f]chromeno[2,3-d] pyrimidine-11(10H)-one (5)}

A mixture of 2 (1 mmol), and aniline (1 mmol) in $20 \mathrm{~mL}$ of pyridine was refluxed for 5 hours. The reaction mixture was concentrated under reduced pressure and the residue triturated with methanol, poured into acidified ice/water and the precipitate formed washed with water thoroughly, dried and crystallized from methanol as buff powder (Scheme 1). Yield: 40 \%. M.p.: $180-182{ }^{\circ} \mathrm{C}$. IR (KBr, $\left.\nu_{\max }, \mathrm{cm}^{-1}\right): 1698$ (CO). ${ }^{1} \mathrm{H}$ NMR (300 MHz, $\left.\mathrm{CDCl}_{3}, \delta, \mathrm{ppm}\right): 7.45$ (s, $1 \mathrm{H}, \mathrm{CH}$-pyrimidine), 7.75-7.97 (m, 17H, Ar-H + CH-pyran). MS (m/z, (\%)): $402\left(\mathrm{M}^{+}\right.$, 15). Anal. calcd. for $\mathrm{C}_{27} \mathrm{H}_{18} \mathrm{~N}_{2} \mathrm{O}_{2}$ (402.44): $\mathrm{C}, 80.58 ; \mathrm{H}, 4.51 ; \mathrm{N}$, 6.96. Found: C, 80.64; H, 4.69; N, 7.02\%.

\subsection{General procedure for synthesis of compounds $(7 a, b)$}

A mixture of 2 ( $1 \mathrm{mmol})$, and hydrazine hydrate (excess) in $20 \mathrm{~mL}$ of dioxane containing $0.1 \mathrm{~mL}$ of triethylamine as catalyst was refluxed for 3 hours. The compound formed during reflux was collected by filtration and re-crystallized from $\mathrm{DMF} / \mathrm{H}_{2} \mathrm{O}$ to form compound $\mathbf{7 a}$. Analogously, compound $\mathbf{2}$ reacted with phenyl hydrazine to afford compound $\mathbf{7 b}$ (Scheme 1).

10-Amino-12-phenyl-12H-benzo[f]chromeno[2,3-d]pyrimi dine-11(10H)-one (7a): Colorless crystals (DMF $\left./ \mathrm{H}_{2} \mathrm{O}\right)$. Yield: 68 \%. M.p.: 280-282 ${ }^{\circ} \mathrm{C}$. IR (KBr, $\left.v_{\max }, \mathrm{cm}^{-1}\right): 1699$ (CO), 3410-3415 $\left(\mathrm{NH}_{2}\right) .{ }^{1} \mathrm{H}$ NMR (300 MHz, $\left.\mathrm{CDCl}_{3}, \delta, \mathrm{ppm}\right): 4.69\left(\mathrm{~s}, 2 \mathrm{H}, \mathrm{NH}_{2}\right), 7.49$ (s, 1H, CH-pyrimidine), 7.76-7.98 (m, 12H, Ar-H + CH-pyran). ${ }^{13} \mathrm{C}$ NMR (75 MHz, $\mathrm{CDCl}_{3}, \delta$, ppm): 39.12, 102.12, 118.12, $120.34,122.12,123.14,126.43,126.71,128.23,128.32,129.23$, $129.32,133.42,140.22,143.21,151.12,153.12,166.23$. MS (m/z, (\%)): $341\left(\mathrm{M}^{+}, 30\right)$. Anal. calcd. for $\mathrm{C}_{21} \mathrm{H}_{15} \mathrm{~N}_{3} \mathrm{O}_{2}$ (341.36): C, 73.89; H, 4.43; N, 12.31. Found: C, 73.96; H, 4.59; N, 12.48\%.
10-(Phenylamino)-12-phenyl-12H-benzo[f]chromeno[2,3d]pyrimidine-11(10H)-one (7b): Colorless crystals (DMF/ $\left.\mathrm{H}_{2} \mathrm{O}\right)$. Yield: 55 \%. M.p.: $230-232{ }^{\circ} \mathrm{C}$. IR (KBr, $\left.v_{\max }, \mathrm{cm}^{-1}\right): 1699$ (CO), $3120(\mathrm{NH}) .{ }^{1} \mathrm{H}$ NMR $\left(300 \mathrm{MHz}, \mathrm{CDCl}_{3}, \delta, \mathrm{ppm}\right): 7.50(\mathrm{~s}, 1 \mathrm{H}, \mathrm{CH}-$ pyrimidine), 7.79-8.12 (m, 17H, Ar-H + CH-pyran), 10.59 (s, $\mathrm{H}_{\text {, }}$ NH). MS (m/z, (\%)): $417\left(\mathrm{M}^{+}, 20\right)$. Anal. calcd. for $\mathrm{C}_{27} \mathrm{H}_{19} \mathrm{~N}_{3} \mathrm{O}_{2}$ (417.46): C, 77.68; H, 4.59; N, 10.07. Found: C, 77.73; H, 4.65; N, $10.15 \%$.

\subsubsection{Ethyl 3-(methylsulfanylthiocarbonylamino)-1-phenyl- 1H-benzo[f]chromene-2-carboxylate (10)}

To a vigorously stirred solution of $\mathbf{1}$ (3.44 g, $0.02 \mathrm{~mol}$ ) in dimethyl sulfoxide $(10 \mathrm{~mL})$ at room temperature, carbon disulfide (1.98 g, $0.02 \mathrm{~mol})$ and aqueous sodium hydroxide $(1.2$ $\mathrm{mL}, 20 \mathrm{M}$ solution) were added simultaneously over $30 \mathrm{~min}$ then the mixture was allowed to stir for additional $30 \mathrm{~min}$ Dimethyl sulfate $(2.5 \mathrm{~g}, 0.02 \mathrm{~mol})$ was added drop wise to the reaction mixture with stirring at $5-10{ }^{\circ} \mathrm{C}$. After further stirring for 2 hours the mixture was poured into ice-water. The solid so obtained was filtered off, dried and crystallized from ethanol/water (Scheme 2). White powder $\left(\mathrm{EtOH} / \mathrm{H}_{2} \mathrm{O}\right)$. Yield: 70 \%. M.p.: 110-112 ${ }^{\circ} \mathrm{C}$. IR (KBr, $\left.v_{\max }, \mathrm{cm}^{-1}\right): 1320$ (C=S), 1699 (CO), $3120(\mathrm{NH}) .{ }^{1} \mathrm{H}$ NMR (300 MHz, $\left.\mathrm{CDCl}_{3}, \delta, \mathrm{ppm}\right): 1.44(\mathrm{t}, 3 \mathrm{H}$, $\left.\mathrm{CH}_{3}\right), 4.14\left(\mathrm{q}, 2 \mathrm{H}, \mathrm{CH}_{2}\right), 4.74\left(\mathrm{~s}, 3 \mathrm{H}, \mathrm{SCH}_{3}\right), 7.78-8.11(\mathrm{~m}, 13 \mathrm{H}$, Ar-H + CH-pyran + NH). MS $(m / z,(\%)): 451\left(M^{+}, 15\right)$. Anal. calcd. for $\mathrm{C}_{25} \mathrm{H}_{25} \mathrm{NO}_{3} \mathrm{~S}_{2}$ (451.6): C, 66.49; $\mathrm{H}, 5.58 ; \mathrm{N}, 3.10$. Found: C, 66.57; H, 5.64; N, 3.23\%

\subsubsection{Ethyl 1-phenyl-1H-3-(hydrazinothiocarbonylamino) benzo[f]chromene-2-carboxylate (11)}

A mixture of 10 (1 mmol), and hydrazine hydrate (excess) in $20 \mathrm{~mL}$ of ethanol containing $0.1 \mathrm{~mL}$ of piperidine as catalyst was stirred at room temperature for 5 minutes. The compound formed was collected by filtration and crystallized from mixture of ethanol and water (3:1) to form compound $\mathbf{1 1}$ (Scheme 2). White powder (EtOH/ $\left.\mathrm{H}_{2} \mathrm{O}\right)$. Yield: 70 \%. M.p.: 240 $242{ }^{\circ} \mathrm{C}$. IR ( $\mathrm{KBr}, v_{\max } \mathrm{cm}^{-1}$ ): 1200 (C=S), $1700(\mathrm{CO}), 3130(\mathrm{NH})$, $3420\left(\mathrm{NH}_{2}\right)$ 


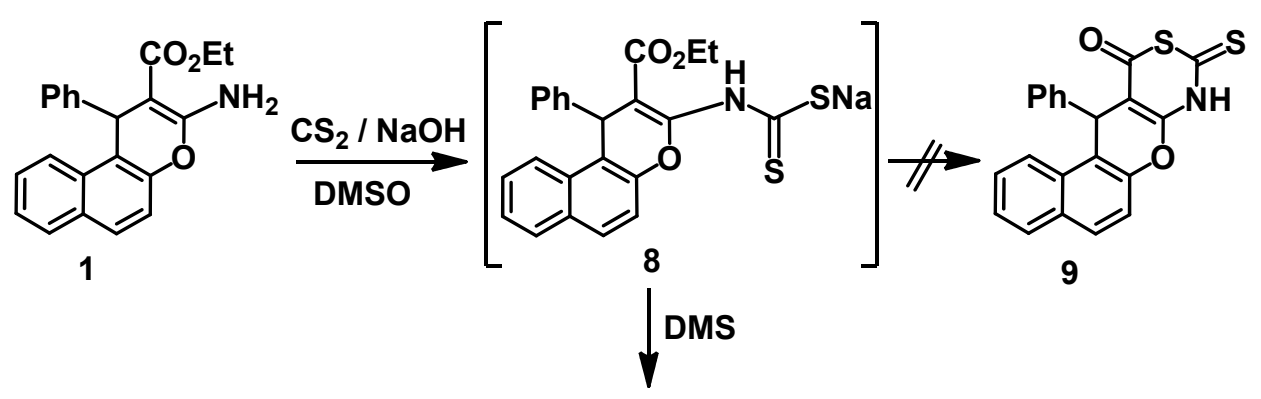<smiles>CCOC(=O)C1=C(NC(=S)SC)Oc2ccc3ccccc3c2C1c1ccccc1</smiles>

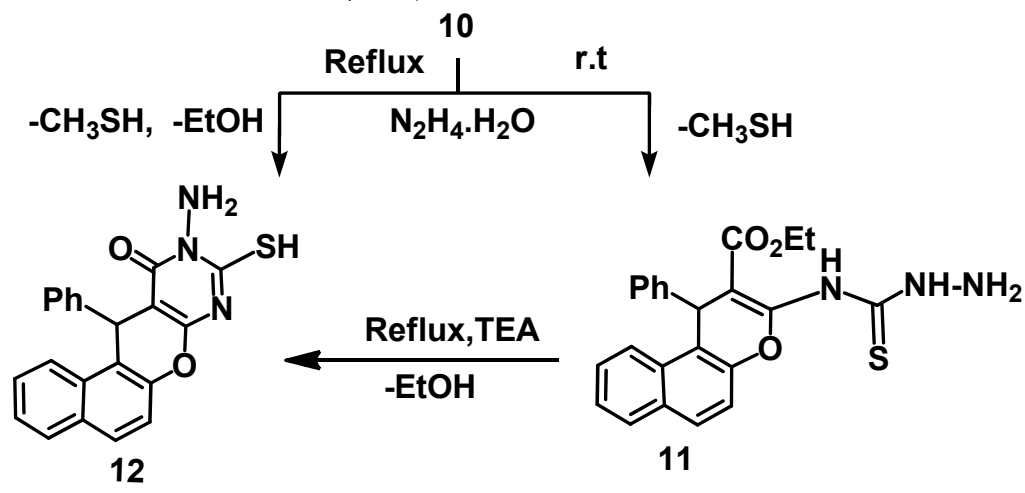

Scheme 2

${ }^{1} \mathrm{H}$ NMR $\left(300 \mathrm{MHz}, \mathrm{CDCl}_{3}, \delta, \mathrm{ppm}\right): 1.47\left(\mathrm{t}, 3 \mathrm{H}, \mathrm{CH}_{3}\right), 2.56(\mathrm{~s}, 2 \mathrm{H}$, $\left.\mathrm{NH}_{2}\right), 4.35$ (q, 2H, $\left.\mathrm{CH}_{2}\right), 7.78-8.17(\mathrm{~m}, 14 \mathrm{H}, \mathrm{Ar}-\mathrm{H}+\mathrm{CH}-\mathrm{pyran}+$ $2 \mathrm{NH})$. MS $(\mathrm{m} / \mathrm{z},(\%))$ : $420\left([\mathrm{M}+1]^{+}, 16\right)$. Anal. calcd. for $\mathrm{C}_{23} \mathrm{H}_{21} \mathrm{~N}_{3} \mathrm{O}_{3} \mathrm{~S}$ (419.5): C, 65.85; $\mathrm{H}, 5.05 ; \mathrm{N}, 10.02$. Found: $\mathrm{C}$, 65.99; H, 5.25; N, 10.24\%.

\subsubsection{0-Amino-12-phenyl-9-sulfanyl-12H-benzo[f] chromeno[2,3-d] pyrimidine-11(10H)-one (12)}

A mixture of $\mathbf{1 0}(1 \mathrm{mmol})$ and hydrazine hydrate (excess) in $20 \mathrm{~mL}$ of ethanol containing $0.1 \mathrm{~mL}$ of piperidine as catalyst was refluxed for 8 hours. The reaction mixture was concentrated under reduced pressure and the residue triturated with methanol, the compound formed was collected by filtration and crystallized from ethanol to form compound 12 (Scheme 2). Colorless crystals (EtOH). Yield: 70 \%. M.p.: 155-157 ${ }^{\circ} \mathrm{C}$. IR (KBr, $\left.v_{\max }, \mathrm{cm}^{-1}\right): 1700$ (CO), 2350 (SH), 3425 $\left(\mathrm{NH}_{2}\right) .{ }^{1} \mathrm{H}$ NMR (300 MHz, $\left.\mathrm{CDCl}_{3}, \delta, \mathrm{ppm}\right): 4.47\left(\mathrm{~s}, 2 \mathrm{H}, \mathrm{NH}_{2}\right)$, 7.78-8.17 (m, 12H, Ar-H + CH-pyran), 10.23 (s, 1H, SH). MS $(\mathrm{m} / \mathrm{z},(\%)): 373\left(\mathrm{M}^{+}, 20\right)$. Anal. calcd. for $\mathrm{C}_{21} \mathrm{H}_{15} \mathrm{~N}_{3} \mathrm{O}_{2} \mathrm{~S}$ (373.43): C, 67.54; H, 4.05; N, 11.25. Found: C, 67.67; H, 4.23; N, 11.34\%.

\subsubsection{General procedure for synthesis of compounds $(15 a, b)$}

Compound 12 (1 mol) in $10 \mathrm{~mL}$ acetic acid and benzaldehyde $(1.5 \mathrm{~mol})$ was acidified to $\mathrm{pH}=5$ with dilute $\mathrm{HCl}$, and the reaction mixture was stirred at $150{ }^{\circ} \mathrm{C}$ for 15 hours. The solution was allowed to stand overnight, then filtered and the resulting precipitate was washed with $5 \% \mathrm{NaHCO}_{3}$ and water to neutrality and then dried, the resulting product was crystallized from ethanol. Analogously, compound 12 reacted with 4-chlorobenzaldehyde to afford compound $\mathbf{1 5 b}$ (Scheme $3)$.

10,14-Diphenyl-14H-benzo[f]chromeno[2,3-d][1,3,4]thia diazolo [3,2-a] pyrimidine-13-one (15a): Yellow crystals (EtOH). Yield: 55 \%. M.p.: $225-227{ }^{\circ}$ C. IR (KBr, $\left.v_{\max }, \mathrm{cm}^{-1}\right): 1700$ (CO). ${ }^{1} \mathrm{H}$ NMR $\left(300 \mathrm{MHz}, \mathrm{CDCl}_{3}, \delta, \mathrm{ppm}\right): 7.78-8.17(\mathrm{~m}, 17 \mathrm{H}, \mathrm{Ar}-\mathrm{H}+\mathrm{CH}-$ pyran). MS $(m / z,(\%)): 459\left(\mathrm{M}^{+}, 15\right)$. Anal. calcd. for $\mathrm{C}_{28} \mathrm{H}_{17} \mathrm{~N}_{3} \mathrm{O}_{2} \mathrm{~S}$ (459.52): C, 73.19; $\mathrm{H}, 3.73 ; \mathrm{N}, 9.14$. Found: $\mathrm{C}$, 73.23; H, $3.87 \mathrm{~N}, 9.35 \%$.

10-(4-Chlorophenyl)-14-phenyl-14H-benzo[f]chromeno[2,3d][1,3,4]thiadiazolo[3,2-a] pyrimidine-13-one (15b): Yellow crystals (EtOH). Yield: $55 \%$. M.p.: $210-212{ }^{\circ} \mathrm{C}$. IR $\left(\mathrm{KBr}, v_{\max }, \mathrm{cm}\right.$ 1): 1700 (CO). ${ }^{1} \mathrm{H}$ NMR $\left(300 \mathrm{MHz}, \mathrm{CDCl}_{3}, \delta, \mathrm{ppm}\right): 7.75-8.19(\mathrm{~m}$, $16 \mathrm{H}, \mathrm{Ar}-\mathrm{H}+\mathrm{CH}-$ pyran$)$. MS (m/z, (\%)): $493\left(\mathrm{M}^{+}, 40\right)$. Anal. calcd. for $\mathrm{C}_{28} \mathrm{H}_{16} \mathrm{ClN}_{3} \mathrm{O}_{2} \mathrm{~S}$ (493.96): C, 68.08; $\mathrm{H}, 3.26$; N, 8.51 . Found: C, 68.24; H, 3.39; N, 8.68\%.

\subsubsection{Ethyl 3-(4-oxo-2-thioxothiazolidin-3-yl)-1-phenyl-1H- benzo[f]chromene-2-carboxylate (18)}

To a vigorously stirred solution of $\mathbf{1}$ (3.44 g, $0.02 \mathrm{~mol}$ ) in dimethyl formamide $(10 \mathrm{~mL})$ at room temperature, carbon disulfide $(1.98 \mathrm{~g}, 0.02 \mathrm{~mol})$ and aqueous potassium hydroxide $(1.2 \mathrm{~mL}, 10 \mathrm{~mol}$ solution) were added simultaneously over 30 min. then the mixture was allowed to stir for additional $30 \mathrm{~min}$ Chloroacetic acid $(0.02 \mathrm{~mol})$ was added drop wise to the reaction mixture with stirring at $5-10{ }^{\circ} \mathrm{C}$, and the mixture was further stirred for 2 hours and poured into ice-water. The solid so obtained was filtered off, dried and crystallized from dioxane $/ \mathrm{H}_{2} \mathrm{O}$ (Scheme 4). Yellow crystals (dioxane $/ \mathrm{H}_{2} \mathrm{O}$ ). Yield: 55 \%. M.p.: $>300$ ㄷ. IR (KBr, $\left.v_{\max } \mathrm{cm}^{-1}\right): 1320$ (C=S), 1700 (CO). 


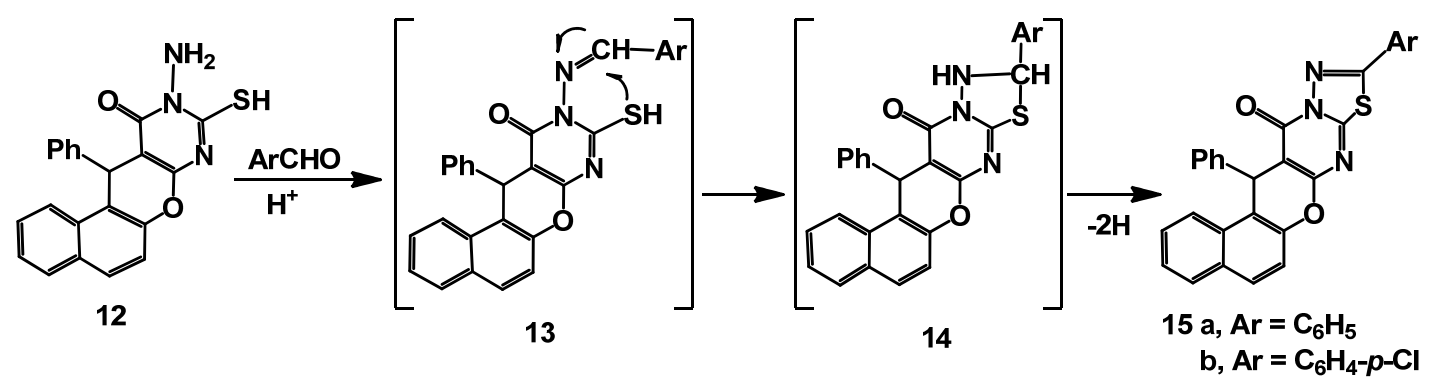

Scheme 3
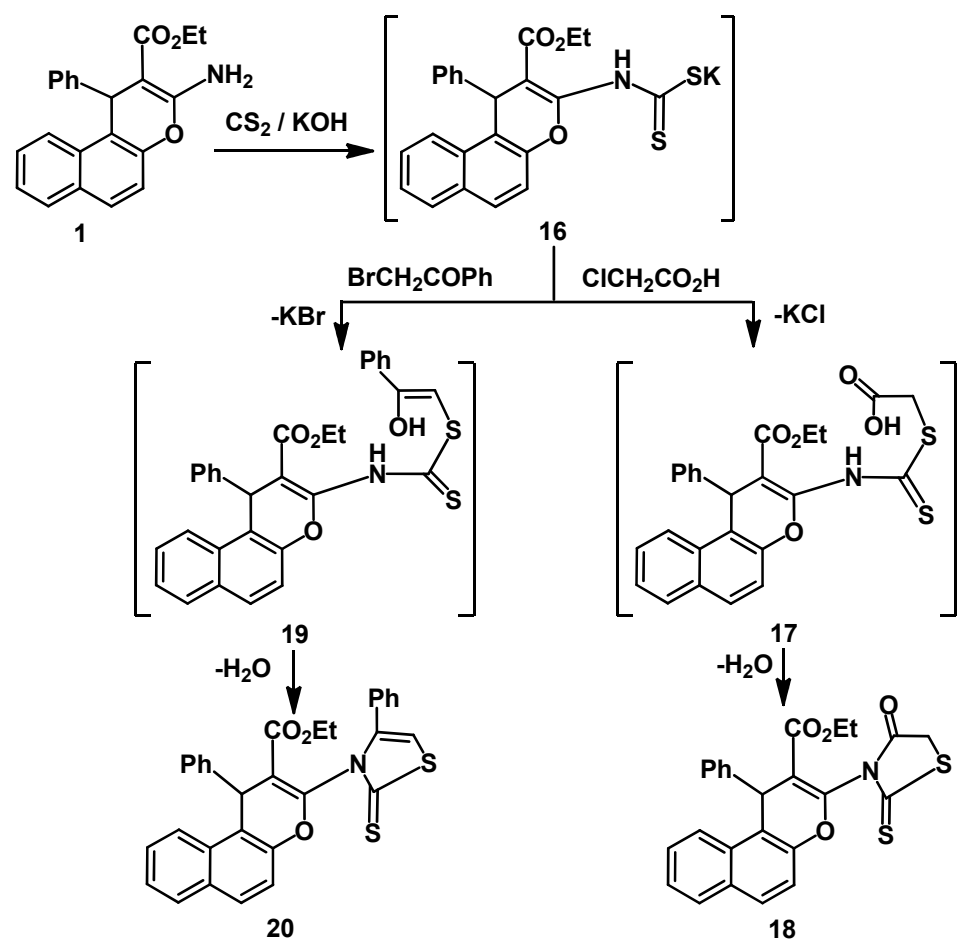

Scheme 4

${ }^{1} \mathrm{H}$ NMR $\left(300 \mathrm{MHz}, \mathrm{CDCl}_{3}, \delta, \mathrm{ppm}\right): 1.54\left(\mathrm{t}, 3 \mathrm{H}, \mathrm{CH}_{3}\right), 4.56(\mathrm{q}, 2 \mathrm{H}$, $\left.\mathrm{CH}_{2}\right), 4.32$ (s, $2 \mathrm{H}$, thiazolyl $\left.\mathrm{CH}_{2}\right), 7.78-8.23(\mathrm{~m}, 12 \mathrm{H}, \mathrm{Ar}-\mathrm{H}+\mathrm{CH}-$ pyran). MS $(\mathrm{m} / \mathrm{z},(\%))$ : $461\left(\mathrm{M}^{+}, 15\right)$. Anal. calcd. for $\mathrm{C}_{25} \mathrm{H}_{19} \mathrm{NO}_{4} \mathrm{~S}_{2}$ (461.55): C, 65.06; $\mathrm{H}, 4.15 ; \mathrm{N}, 3.03$. Found: $\mathrm{C}$, 65.21; H, 4.34; N, 3.23\%.

\subsubsection{Ethyl 3-(4-phenyl-2-thioxothiazol-3(2H)-yl)-1-phenyl- 1H-benzo[f]chromene-2-carboxylate (20)}

To a vigorously stirred solution of $1(3.44 \mathrm{~g}, 0.02 \mathrm{~mol})$ in dimethyl formamide $(10 \mathrm{~mL})$ at room temperature, carbon disulfide (1.98 g, $0.02 \mathrm{~mol}$ ) and aqueous potassium hydroxide (1.2 mL, $10 \mathrm{M}$ solution) were added simultaneously over 30 $\mathrm{min}$, then the mixture was allowed to stir for additional $30 \mathrm{~min}$. Phenacyl bromide $(0.02 \mathrm{~mol})$ was added drop wise to the reaction mixture with stirring at $5-10{ }^{\circ} \mathrm{C}$. The mixture was further stirred for 2 hours and poured into ice-water. The solid so obtained was filtered off, dried and crystallized from dioxane $/ \mathrm{H}_{2} \mathrm{O}$ (Scheme 4). Greenish yellow crystals (dioxane/ $\mathrm{H}_{2} \mathrm{O}$ ). Yield: 50 \%. M.p.: $>300{ }^{\circ} \mathrm{C}$. IR $\left(\mathrm{KBr}, v_{\max }, \mathrm{cm}^{-1}\right)$ :
1325 (C=S), 1690 (CO). ${ }^{1} \mathrm{H}$ NMR (300 MHz, $\left.\mathrm{CDCl}_{3}, \delta, \mathrm{ppm}\right): 1.58$ $\left(\mathrm{t}, 3 \mathrm{H}, \mathrm{CH}_{3}\right), 4.34\left(\mathrm{q}, 2 \mathrm{H}, \mathrm{CH}_{2}\right), 7.78-8.23(\mathrm{~m}, 18 \mathrm{H}, \mathrm{Ar}-\mathrm{H}+\mathrm{CH}-$ pyran + CH-thiazole). MS $(\mathrm{m} / \mathrm{z},(\%)): 508\left(\mathrm{M}^{+}, 40\right), 510(\mathrm{M}+2$, 9). Anal. calcd. for $\mathrm{C}_{30} \mathrm{H}_{22} \mathrm{NO}_{3} \mathrm{~S}_{2}$ (508.63): $\mathrm{C}, 70.84 ; \mathrm{H}, 4.36$; N, 2.75. Found: C, 70.99; H, 4.46; N, 2.91\%.

\subsubsection{Ethyl 3-acetamido-1-phenyl-1H-benzo[f]chromene-2-} carboxylate (21)

A mixture of $1(0.004 \mathrm{~mol})$, acetic anhydride $(0.012 \mathrm{~mol})$ and zinc dust $(0.28 \mathrm{~g})$ was refluxed on water bath for 4 hours with stirring and filtered hot. The resulting clear solution was cooled to room temperature and the solid so obtained was filtered off (Scheme 5). Colorless crystals (dioxane $/ \mathrm{H}_{2} \mathrm{O}$ ). Yield: 70 \%. M.p.: 120-122 ${ }^{\circ} \mathrm{C}$. IR (KBr, $\left.v_{\max }, \mathrm{cm}^{-1}\right): 1695$ (CO), 3120 (NH). ${ }^{1} \mathrm{H}$ NMR (300 MHz, $\left.\mathrm{CDCl}_{3}, \delta, \mathrm{ppm}\right): 1.58\left(\mathrm{t}, 3 \mathrm{H}, \mathrm{CH}_{3}\right), 2.43$ (s, $\left.3 \mathrm{H}, \mathrm{COCH}_{3}\right), 4.39\left(\mathrm{q}, 2 \mathrm{H}, \mathrm{CH}_{2}\right), 7.78-8.23(\mathrm{~m}, 12 \mathrm{H}, \mathrm{Ar}-\mathrm{H}+\mathrm{CH}-$ pyran), $10.23(\mathrm{~s}, 1 \mathrm{H}, \mathrm{NH})$. MS ( $\mathrm{m} / \mathrm{z},(\%)): 387\left(\mathrm{M}^{+}, 30\right)$. Anal. calcd. for $\mathrm{C}_{24} \mathrm{H}_{21} \mathrm{NO}_{4}$ (387.43): C, 74.40; H, 5.46; N, 3.62. Found: C, 74.53; H, 5.59; N, 3.76\%. 


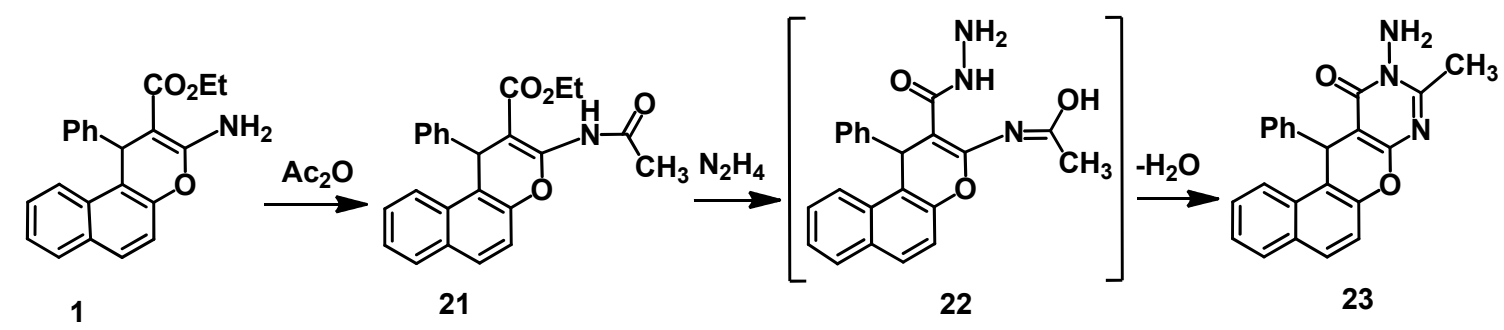

Scheme 5

\subsubsection{0-Amino-9-methyl-12-phenyl-12H-benzo[f] chromeno[2,3-d]pyrimidine-11(10H)-one (23)}

To a solution of $\mathbf{2 1}(0.014 \mathrm{~mol})$ in absolute ethanol $(10 \mathrm{~mL})$ hydrazine hydrate $(80 \%, 0.14 \mathrm{~mol})$ was added and the reaction mixture was heated for 3 hours on a water bath. The reaction mixture was cooled to room temperature and the solid so obtained was filtered off as colorless crystals, (dioxane $/ \mathrm{H}_{2} \mathrm{O}$ ) (Scheme 5). Yield: 60 \%. M.p.: $165-167{ }^{\circ} \mathrm{C}$. IR $\left(\mathrm{KBr}, \nu_{\max }, \mathrm{cm}^{-1}\right)$ : 1695 (CO), $3420\left(\mathrm{NH}_{2}\right) .{ }^{1} \mathrm{H}$ NMR $\left(300 \mathrm{MHz}, \mathrm{CDCl}_{3}, \delta, \mathrm{ppm}\right): 1.60$ (s, 3H, $\left.\mathrm{CH}_{3}\right), 2.12\left(\mathrm{~s}, 2 \mathrm{H}, \mathrm{NH}_{2}\right), 7.78-8.23(\mathrm{~m}, 12 \mathrm{H}, \mathrm{Ar}-\mathrm{H}+\mathrm{CH}-$ pyran). MS (m/z, (\%)): $355\left(\mathrm{M}^{+}, 30\right)$. Anal. calcd. for $\mathrm{C}_{22} \mathrm{H}_{17} \mathrm{~N}_{3} \mathrm{O}_{2}$ (355.39): C, 74.35; H, 4.82; N, 11.82\%. Found: C, 74.46; H, 4.99; $\mathrm{N}, 11.93 \%$.

\section{Results and discussion}

Ethyl 3-(dimethylaminomethyleneamino)-1-phenyl- $1 \mathrm{H}$ benzo[f]chromene-2-carboxylate (2) was prepared by the reaction of ethyl 3-amino-1-phenyl- $1 H$-benzo[f]chromene-2carboxylate (1) with dimethyl formamide in presence of phosphorus oxychloride, (Scheme 1). The structure of this compound was characterized by IR, ${ }^{1} \mathrm{H}$ NMR, mass spectroscopy and elemental analysis. The ${ }^{1} \mathrm{H}$ NMR showed specifically a singlet at $2.47 \mathrm{ppm}$ for the two methyl groups of the dimethylamino moiety and $7.54 \mathrm{ppm}$ of the formamidine proton and the typical ester absorption pattern. Also, its IR showed disappearance of the amino absorption at 3300-3400 $\mathrm{cm}^{-1}$. It is plausible to expect that compound $\mathbf{2}$ would yield new tetracyclic compounds when reacted with amine derivatives. Thus, treatment of compound $\mathbf{2}$ with aromatic amine in refluxing ethanol afforded a product which had $\mathrm{m} / \mathrm{z}$ at 420 which is incompatible with our expectation. So, it was assumed that the reaction proceeded via losing $N$-dimethylamine to give the intermediate $\mathbf{3}$ which underwent hydrolysis rather than cyclization via losing ethanol yielding what we expected as product 5, (Scheme 1). While repeating this reaction in pyridine at reflux for five hours afforded the expected 10,12diphenyl-12H-benzo[f]chromeno[2,3- $d$ ] pyrimidine-11 $(10 H)$ one 5. Compound 5 formed via losing of $\mathrm{N}$-dimethylamine to give the intermediate $\mathbf{3}$ which cyclized through releasing of ethanol. The mass spectroscopy of compound $\mathbf{5}$ showed $\mathrm{m} / \mathrm{z}$ at 405 which is compatible with its molecular weight. On the other hand, compound 2 reacted with substituted hydrazine to yield the corresponding chromeno[2,3-d]pyrimidine derivatives 7a,b via elimination of ethanol from the corresponding intermediate $\mathbf{6}$ which cyclized via release of ethanol. The IR spectrum of 7a showed absorption bands at 3410-3415 $\left(\mathrm{NH}_{2}\right)$ and at $1699 \mathrm{~cm}^{-1}$ for the $\mathrm{CO}$ function. The ${ }^{1} \mathrm{H}$ NMR spectrum of compound 7a showed two singlets at $\delta 4.69$ and $7.49 \mathrm{ppm}$ due to amino and pyrimidino protons, respectively.

On the other hand, a solution of compound $\mathbf{1}$ in dimethyl sulfoxide was treated with carbon disulfide in presence of sodium hydroxide solution. The sodium salt of dithiocarbamic acid $\mathbf{8}$ was obtained in situ and then methylated with dimethyl sulfate to yield ethyl 3-(methylsulfanylthiocarbonylamino)-1phenyl-1H-benzo[f]chromene-2-carboxylate (10) (Scheme 2). The structure of compound $\mathbf{1 0}$ was confirmed by IR, ${ }^{1} \mathrm{H}$ NMR, and mass spectroscopy and elemental analysis. The IR spectrum of compound $\mathbf{1 0}$ showed the disappearance of absorption bands characterized for amino function and showed the presence of absorption bands at $v 1320 \mathrm{~cm}^{-1}$ due to $\mathrm{C}=\mathrm{S}$ and $3120 \mathrm{~cm}^{-1}$ due to the $\mathrm{NH}$ function. The ${ }^{1} \mathrm{H}$ NMR spectrum of compound 10 showed a singlet at $\delta 4.74 \mathrm{ppm}$ due to $\mathrm{SCH}_{3}$ protons. However, compound $\mathbf{1 0}$ containing several reactive functions represented a good intermediate for further reactions when treated with hydrazine hydrate. So, compound $\mathbf{1 0}$ when reacted with hydrazine hydrate in ethanol with stirring at room temperature yielded the open chain thiosemicarbazide derivative $\mathbf{1 1}$ via elimination of methylsulfane, while, under reflux in ethanol for 8 hours, it yielded the expected benzo[f]chromeno[2,3- $d$ ] pyrimidine $\mathbf{1 2}$ via elimination of methylsulfane and ethanol. Boiling the thiosemicarbazide $\mathbf{1 1}$ in ethanol in presence of triethylamine yielded the same compound 12. The IR spectrum of $\mathbf{1 1}$ showed the presence of absorption bands at $v 1200 \mathrm{~cm}^{-1}$ due to $\mathrm{C}=\mathrm{S}, 1700 \mathrm{~cm}^{-1}$ due to $\mathrm{C}=0,3130 \mathrm{~cm}^{-1}$ due to $\mathrm{NH}$ and $3420 \mathrm{~cm}^{-1}$ due to the $\mathrm{NH}_{2}$ function. The ${ }^{1} \mathrm{H}$ NMR spectrum of compound 11 showed a singlet at $\delta 2.56 \mathrm{ppm}$ due to the $\mathrm{NH}_{2}$ protons. The MS of $\mathbf{1 1}$ showed a peak at $m / z 420\left([\mathrm{M}+1]^{+}, 16 \%\right)$. The IR spectrum of 12 showed the presence of absorption bands at $v 1700 \mathrm{~cm}^{-1}$ due to $\mathrm{C}=0,2350 \mathrm{~cm}^{-1}$ due to $\mathrm{SH}$ and $3425 \mathrm{~cm}^{-1}$ due to the $\mathrm{NH}_{2}$ function. However, the ${ }^{1} \mathrm{H}$ NMR spectrum of compound 12 showed the disappearance of absorption signals characteristic for ester protons and two singlets at $\delta 4.47 \mathrm{ppm}$ and at 10.23 ppm due to $\mathrm{NH}_{2}$ and $\mathrm{SH}$ protons, respectively. The MS of $\mathbf{1 2}$ showed a peak at $m / z 373\left(\mathrm{M}^{+}, 20 \%\right)$.

Aimed at the preparation of some new derivatives of $\beta$ lactones and/or thiazolidinone, compound $\mathbf{1 2}$ was allowed to react with benzaldehyde and / or 4-chlorobenzaldehyde to give the corresponding expected Schiff's base 13. However, the isolated compounds proved to be the new and unexpected compounds 15a,b formed via simultaneous nucleophilic attack of the sulfur atom on the hydrazone carbon with cyclization to the new thiadiazole derivatives $\mathbf{1 5 a}, \mathbf{b}$, as shown in Scheme 3.

Furthermore compound 1, when treated with carbon disulfide and potassium hydroxide solution, yielded the soluble potassium salt of dithiocarbamic acid $\mathbf{1 6}$ which was further treated in situ with chloroacetic acid and phenacylbromide, respectively, to afford ethyl 3-(4-oxo-2-thioxothiazolidin-3-yl)1-phenyl-1H-benzo[f]chromene-2-carboxylate (18) and ethyl 1-phenyl-3-(4-phenyl-2-thioxothiazol-3(2H)-yl)- $1 H$-benzo[f] chromene-2-carboxylate (20) via release of water from the two corresponding intermediates $\mathbf{1 7}$ and $\mathbf{1 9}$, respectively (Scheme 4). The structures of compounds $\mathbf{1 8}$ and $\mathbf{2 0}$ were confirmed by IR, ${ }^{1} \mathrm{H}$ NMR, mass spectroscopy and elemental analysis (see experimental section).

Finally, compound $\mathbf{1}$ was acylated with acetic anhydride yielding the acetyl derivative $\mathbf{2 1}$ which easily reacted with hydrazine hydrate to afford the new substituted 10-amino-9methyl-12-phenyl-12H-benzo[f]chromeno[2,3-d]pyrimidine- 
11(10H)-one (23) via intermediate $\mathbf{2 2}$ which formed from $\mathbf{2 1}$ by displacement of ethanol rather than water as shown in Scheme 5. The IR spectrum of $\mathbf{2 3}$ showed the presence of absorption band at $v 1710 \mathrm{~cm}^{-1}$ due to $\mathrm{C}=0$ and $3420 \mathrm{~cm}^{-1}$ due to $\mathrm{NH}_{2}$ function. The ${ }^{1} \mathrm{H}$ NMR spectrum of compound 23 showed two singlets at $\delta 1.53$ and $2.57 \mathrm{ppm}$ due to $\mathrm{CH}_{3}$ and $\mathrm{NH}_{2}$ protons, respectively, with disappearance of absorption pattern of ester protons confirming the proposed rationale of losing ethanol. The MS of 23 showed $m / z$ at $355\left(\mathrm{M}^{+}, 15 \%\right)$.

\section{References}

[1]. Curini, M.; Cravotto, G.; Epifano, F.; Giannone, G. Curr. Med. Chem. 2006, 13, 199-222.

[2]. El Agrody, A. M.; Abd El Latif, M. S.; El Hady, N. A.; Fakery, A. H.; Badair, A. H. Molecules 2001, 6, 519-527.

[3]. Badair, A. H.; El Hady, N. A.; Abd El Latif, M. S.; Fakery, A. H.; El Agrody, A. M. Farmaco 2000, 55, 708-714.

[4]. El Agrody, A. M.; El Hakim, M. H.; Abd El Latif, M. S.; Fakery, A. H.; El Sayed, E. S. M.; El Ghareab, K. A. Acta Pharm. 2000, 50, 111-120.

[5]. Smith, W. P.; Sollis, L. S.; Howes, D. P.; Cherry, C. P.; Starkey, D. I.; Cobley, N. K. J. Med. Chem. 1998, 41, 787-797.

[6]. Taylor, R. N.; Cleasby, A.; Singh, O.; Sharzynski, T.; Wonacott, J. A.; Smith, W. P.; Sollis, L. S.; Howes, D. P.; Cherry, C. P.; Bethell, R.; Colman, P. J. Med. Chem. 1998, 41, 798-807.

[7]. Quagliato, D. A. US 5, 171, 857, Chem. Abstr., 118 (1993) 233887q.

[8]. Oganesyan, E. T.; Tuskaev, V. A.; Saraf, A. S.; Sarkisov, L. S. Russ, Ru 2, 039, 747, Chem. Abstr. 124 (1996) 316989z.

[9]. Koga, H.; Nabata, N.; H. PCT INT APP WO 92, 14 439, Chem. Abstr. 118 (1993) 233885n.

[10]. Martinez, A. G.; Marco, L. G.; Bioorg. Med. Chem. Lett. 1997, 7, 31653170.

[11]. Dell, C. P.; Smith. C. W. European Patent Appl. EP537949. Chem. Abstr. 119 (1993) 139102d.

[12]. Bianchi, G.; Tava, A. Agric, Biol. Chem. 1987, 51, 2001-2002.

[13]. Mohr, S. J.; Chirigos, M. A.; Fuhrman, F. S.; Pryor, J. W. Cancer Res. 1975, 35, 3750-3754.

[14]. Eiden, F.; Denk, F. Arch. Pharm. (Weinheim Ger.) 1991, 324, 353-354.

[15]. Kenny, R. S.; Mashelkar, U. C.; Rane, D. M.; Bezawada, D. K. Tetrahedron 2006, 62, 9280-9288.

[16]. Brun, P.; Guglielmetti, R.; Pepe, G.; Anguille, S. J. Photochem. Photobiol. A. Chem. 2003, 156, 77-82.

[17]. Eman, A. El Rady.; Magda, A. B. J. Heterocyclic Chem. 2008, 45, 12331236.

[18]. Eman, A. El Rady.; Mohamed, A. K. J. Chinese Chem. Soc. 2004, 51, 779784.

[19]. Fawi, M. A. El Latif.; Eman, A. El Rady.; Mohamed, A. K. Phosphorus Sulfur 2002, 177, 2497-2505.

[20]. Eman, A. El Rady.; Magda, A. B. J. Heterocyclic Chem. 2006, 43, 243247. 